\title{
LEJONG TAU, A DIORAMA OF CONFLICT RESOLUTION BASED ON LOCAL WISDOM
}

\author{
Faizal Kurniawan \\ Winin Maulidya Saffanah \\ IKIP Budi Utomo Malang \\ faizal.pssbu@gmail.com \\ wininwinin@gmail.com
}

\begin{abstract}
This study aims to find out in depth the meaning of Lejong that defines "visiting", typical local wisdom of Manggarai. Lejong is convinced as an effort to solve the conflict faced by Manggarai's students in Malang. This research was conducted on some of Manggarai's student communities in Malang, including IKAMMA, IMAMA, and others. This research focused on students who carried out the only Lejong activities, opened in depth about the meaning of Lejong as the local identity of the Manggarai community, especially in conflict management.

The results of this study are the existence of local values accepted in the identity of the Manggarai community that has been rooted for a long time ago. It is undoubted that the role of senior in upholding the local identity of the Manggarai community, who are overseas, is also one of the "effective ways" in resolving conflicts that occur between Manggarai's students in Malang. This research is limited only to the Manggarai's students. The hope of this research is to contribute to the study of literature on conflict resolution based on local wisdom.
\end{abstract}

\section{Introduction}

Every interaction between people, between groups, and between countries is never clear from the content of the interests in terms of mastery, hostility, and suppression. These are the natural social concepts that often occur in every life with social humanity. Love and empathy are like thin layers that are not able to maintain a permanently harmonious relationship in order that humans develop a wide range of knowledge, values, and social rules as commonly called norms within the limits of vulnerability in social interaction. The vulnerable condition can be fragile and explode at any time into a conflict. In a critical situation, it may be possible that problem-solving cannot be achieved completely, because social relations heated by the interests and behavior hostilities are detached from the procedures of social norms and values. This condition has formed a social interaction crisis where the subject falls into various choices to drop and negate other subjects.

Subsequently, violence, in the end, is the instrument most often used in social 
crises. It is an instinct in a case in which violence is often the final way to resolve a case that indicates there are no other alternatives in resolving a conflict other than violence. As a logical consequence, the social crisis, which manifests itself as violent conflict, is able to achieve a state of the balancing values in social norms, which in the context of the technique is called a solution for all parties. Problem-solving is a condition created through a synergistic and dynamic process from various interest groups in relationship conflict, (Novri: 2009)

The unbalancing situation of the tapering interaction process in such of conflict also often exists to students from East Nusa Tenggara (Nusa Tenggara Timur - NTT) in Malang City. Of course, this will be a particular concern given the massive conflict involving the NTT students in this city, starting from the small-scale level to inter-universities conflict. It leads to serious violence that threatens the social harmony between students and local residents. Actually, local people will always create negative thinking about the presence of immigrant students, especially from NTT students. However, the undeniable impact is that the universities as the related-student campus must accept social sanctions in the form of negative sentiments. As in the last case of 2016, the NTT students involved a certain conflict. Unfortunately, conflict is always resolved in the way of violence, even to the point of taking casualties (Sri Wahyuni: 2016). It is still in line with the statement above that a conflict can only be resolved by violence.

However, the reference in this study is how to resolve a conflict after conflict "post-conflict". Post-conflict is an appropriate time when the resolution is carried out by reaffirming the weakened pillars, alleviating friction, and reuniting differences of existing interests in a conflict case. If there is unsuitable conflict resolution in handling conflict, logically the conflict will be a wider case and have even the bigger adverse effect. An approach to conflict resolution based on local wisdom is the paramount side for conflict resolution efforts in neutral areas. As we know, local wisdom for conflict is all the views or teachings of life where the suggestions, words, values, and traditions will be more glorified or respected in their efforts to achieve a minimum conflict resolution. This model can be run as a socio-cultural mechanism contained in the traditions of the Indonesian people. This is believed and has proven to be more effective in gathering brotherhood and solidarity between cultural owners who have institutionalized and crystallized in social and cultural order.

In the Manggarai culture, Lejong Tau will be discussed deeply in this study. Based on the circumstances, the culture of solidarity between students and people from Manggarai living in Malang has long been established. They have preserved it on the basis of their local spirit in social lives in this city, in which the Lejong Tau culture is a culture of visiting, 
staying in touch, and making in closeness between fellow Manggarai's students in the overseas area. In this culture, there are various kinds of activities to familiarize fellow people from NTT in Malang.

It is this local wisdom considered deliberately to anticipate negative sentiments or assumptions about fellow students from NTT. The more often they carry out activities, the more familiarity will be. In Lejong Tau Nada, a public space discussion takes the form of sharing where each acceptance of the conflict will be resolved in the form of kinship tie as it is closely related to that local wisdom. Sabina states that there are values contained in the Manggarai culture in the context of this visiting approach (Sabina: 2017). Through the view of "data beo", it gets an agreement. Therefore, these are the basis of the researchers taking the title of "Lejong Tau, A Diorama of Conflict Resolution Based on Local Wisdom".

\section{Theoretical Perspective}

In this study, the theory used as a proper tool to analyze is a functional structural theory aimed to find out the interconnected parts. This perspective is intended to grasp the social needs known through notions that are interconnected parts (Fajri: 2016). Society, in this thought, will be seen as a biological unit where one organ will be related to another organ.

This theory also views that harmony in society is strongly determined by the effectiveness of consensus values where the system creates a balance between interconnected elements. In the context of this research, what is meant by parts is the acceptance of local values from the concept of Lejong culture because this is as part of a respected honorable value. The Manggarai student group is a recipient of the local wisdom value, while the conflict acts as a part to be resolved through this Lejong culture.

\section{Methods}

This study uses a qualitative approach to get an overview of the results of the study. This study is classified as qualitative descriptive research because one of the reasons is that this cannot be separated from its context. According to Nasution, in essence, it is observing other people in their environmental life, interacting with them and understanding their language and interpretation of the world around them (Nasution: 2003).

Furthermore, qualitative methods are also used to answer questions called research questions. The question must be in accordance with the concept to be studied. This research will be more relevant using a qualitative approach by delivering qualitative methods. In general, case studies are strategies that are more suitable if the subject of the research question relates to how or why (Robert 2003).

The data sources in this study are divided into two types, namely primary data 
and secondary data. First, the source of primary data is obtained through the results of in-depth interviews with respondents. The main respondents are the NTT students who are in Malang. Then, the sampling technique is purposive sampling because not all of NTT students in Malang implement the Lejong local wisdom. The selection of respondents is rooted in the purpose of earning the primary data.

The source of secondary data is the supporting books and the references related to the entire research. As a reference to discussing local wisdom-based conflict resolution, other sources are previous research journals related the study. Therefore, both of these data sources mutually reinforce the findings of research data in order to get truly valid data.

\section{Discussion}

Based on the result of observations and interviews, the manifestation of Lejong Tau culture that is displayed in Malang appears in the involvement of all Manggarai students consisting of four regions in several distinct meetings. Those hold regular meeting activities according to a predetermined schedule as well as collecting funds or holding social gathering ahead of important public events such as; celebrating major holidays particularly eating together before Christmas and New Year, graduation parties, new student admissions events, pray together, and friendly matches amongst the regions with the big families of Manggarai students in Malang. This is similar to what the Gaudens, a senior student of Manggarai in Malang, said that:

"The manifestation of the Lejong Tau culture displayed in Malang city appears in the participation of Manggarai's students in general activities. Such are regular meetings, fundraising or holding social gatherings for eating together before the Christmas and New Year parties, graduation ceremonies, new student admissions events, member birthday events celebrated together, joint prayers, friendly matches between regional places and refreshing activities together with chatting taking off tired in a togetherness."

It is very interesting that the activities in the Lejong Tau process are very supportive of Manggarai's students to know each other and foster intimacy in brotherhood tie because it involves all students from four different regions. As stated by the Gaudens, the common activities like these are usually carried out in one place in which if the event is indoor it held in Pisang Candi in Lembah Dieng, while if the event is outdoor generally it holds in fields such as in Kelabang Kanjuruhan and in Alap-alap Belimbing. The organizers of these public activities are normally chosen from each student member in each region. This is intentionally done so 
that all Manggarai's students from 4 regions are actively involved.

Moreover, according to Arnoldus S. Ambong, the apparatus of the Manggarai's student from the Pisang Candi area, the realization of Lejong Tau culture carried out by Manggarai students in every region in daily lives is lonto leok laica agu rongko, eme toe coffee inung tuak (chatting/joking/ staying up while smoking, drinking coffee or drinking tuak if it is provided). Besides that, Arnold also emphasized that for Manggarai people, the tuak (like beer) is a drink of peace that makes jokes and laughter, so that it is intimacy as well as giving and receiving when there are big obstacles. Until now, drinking tuak (inung tuak) has become a tradition for Manggarai people so that without Tuak, the
Manggarai traditional events would have experienced in tasteless.

Therefore, Based on the result of observations and interviews, the manifestation of Lejong Tau culture that is displayed in Malang appears in the involvement of all Manggarai students consisting of four regions in several distinct meetings. Those hold regular meeting activities according to a predetermined schedule as well as collecting funds or holding social gathering ahead of important public events such as; celebrating major holidays particularly eating together before Christmas and New Year, graduation parties, new student admissions events, pray together, and friendly matches amongst the regions with the big families of Manggarai students in Malang.

Table for Early Conversation Begins Lejong Tau Process

\begin{tabular}{|c|l|l|}
\hline No & \multicolumn{1}{|c|}{ Conversation } & \multicolumn{1}{|c|}{ Meaning in English } \\
\hline 1 & Lejong ce'e ite bo ko ite /kereng & $\begin{array}{l}\text { You came to visit earlier/ you came on a } \\
\text { cruise earlier }\end{array}$ \\
\hline 2 & $\begin{array}{l}\text { Oleh ite / kereng lonto di ew, aku pande } \\
\text { kopi kudut ite }\end{array}$ & $\begin{array}{l}\text { Sit down for a while, I'll make coffee for } \\
\text { you }\end{array}$ \\
\hline 3 & $\begin{array}{l}\text { Oleh ite/kereng diam manga perlu penting } \\
\text { lenjong ce'e ho bo ge }\end{array}$ & $\begin{array}{l}\text { Do you have important needs to come } \\
\text { visiting here }\end{array}$ \\
\hline 4 & $\begin{array}{l}\text { Asi hidi hada kole tong,olong jumik cama- } \\
\text { cama ce mbaru }\end{array}$ & $\begin{array}{l}\text { Don't rush home later, we will have } \\
\text { breakfast together at home }\end{array}$ \\
\hline 5 & $\begin{array}{l}\text { Asan koe kabar dised sina mbaru,diam } \\
\text { ngai sehat de lite }\end{array}$ & $\begin{array}{l}\text { How the news of the people in your } \\
\text { home, are they still fine? }\end{array}$ \\
\hline 6 & $\begin{array}{l}\text { Ho'os cekoe oleh-oleh kudut ba'a ata sina } \\
\text { mbaru lite tong }\end{array}$ & $\begin{array}{l}\text { This is a little gift from me for people in } \\
\text { your house }\end{array}$ \\
\hline 7 & $\begin{array}{l}\text { Salam latang ised ata sina mbaru daku } \\
\text { lite,dan de dia ite lako tong ge,dan } \\
\text { terimakasi lite bo ga ai lejong ce mbaru }\end{array}$ & $\begin{array}{l}\text { Greetings to your house people from } \\
\text { me, and be careful on the way, I wish } \\
\text { you safely home and thank you for } \\
\text { visiting here }\end{array}$ \\
\hline
\end{tabular}


The dialogue process above is a sign of how to pay attention in the form of questions. There is a sense of affection in the process of starting "visiting". The topic is not to tell about his situation but to ask others as a form of lowering his selfishness.

The next stage is to present foods and drinking to guests in which the way of treats handed over to guests are also like their habits in Manggarai. Likewise, the type of dish is also the same in the concept of visiting Indonesia in general that it can be enjoyed together.

\section{Lejong Tau as an Effort to Resolve Conflict}

\section{Based on Local Wisdom}

Lejong Tau culture is one of the Manggarai's local wisdom which is still respected and believed by students in settling their own problems. In the process of Lejong Tau pathway, the respect for a cultural context of visiting and friendship is very emphasized, as well as understanding this local wisdom as an agreement that is sacred or respected is very indispensable. It is a culture of resolving the problem in a form of consensus. In the following chart, we will explain the processes and stages in Lejong Tau

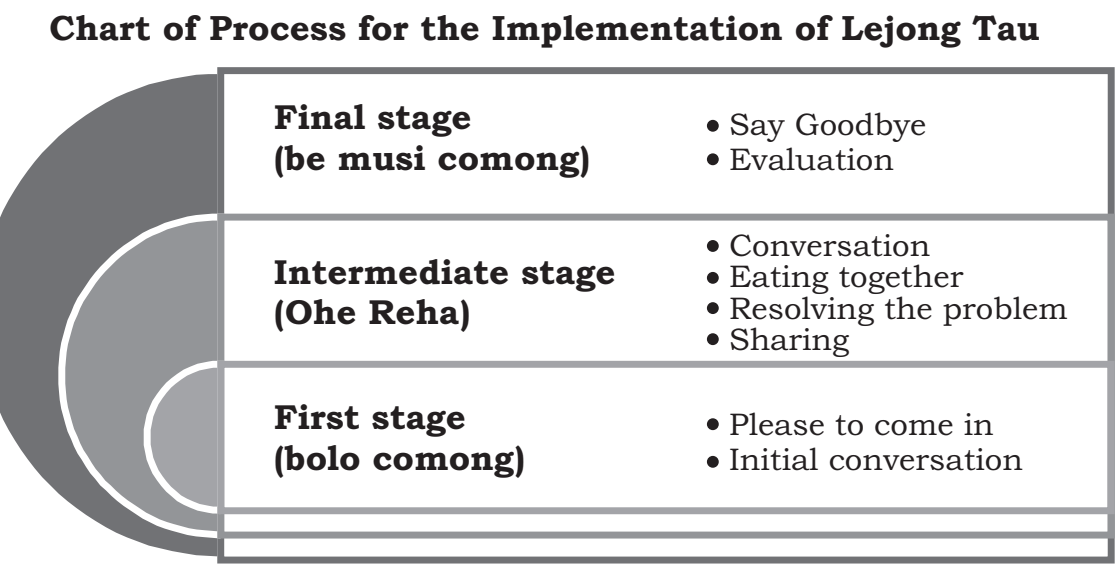

The first stage (bolo comong) in the context of Lejong Tau is to invite all participants. The host here serves as a mediator and servant for the holding of the entire Lejong Tau activities. The host also provides all the usual consumption processes that are normally used like beer, coffee, sugar, cigarettes, betel, and other snacks. The next stage is the intermediate level that is also referred to as core step (be musi comong). In this level, the purpose of the visiting activity is delivered. Therefore, the settlement of the conflict is done at the intermediate stage because at this stage is usually the meaning of the Lejong context or visiting. The discussions of what is conveyed through a democratic forum involving all Lejong participants by making decisions 
agreed upon by all. No wonder if the peak of the conflict occurs at this stage. The final stage is often called be musi comong that carries out an agreement to decide, in which determine the agreement of the entire Lejong process is from beginning to end.

Furthermore, resolving conflicts in Indonesia always starts with local wisdom according to Fajri (Fajri: 2016). Alamsyah also said that local wisdom as a conflict resolution within a family, and the family, in this case, is the Manggarai student community. More importantly, the existentialism of the Manggarai's local identity, in this case, is accepted to respect traditional values in its efforts to resolve conflicts in a family forum. In line with Sriyanto's statement, familybased solutions will help to tackle conflict because the culture is deeply rooted and not oriented solely in profane, but also aimed in a sacred manner so that the process of implementation will be more quickly accepted in the community.

\section{Conclusion}

Lejong Tau is one of the local wisdom of the Manggarai community existing in the overseas region. Lejong Tau has often been used as mediation for warring groups. The accepted and sacred local values are what encourage conflicting groups to deal with their conflicts and finish them to completion. Moreover, local values greatly determine the effectiveness of consensus values where the value system always works and creates equilibrium. In the Lejong context, there is an acceptance of local values in the Manggarai community. Lejong Tau also functions in resolving the conflicts between groups within the Manggarai community. Therefore, local wisdom-based conflict resolution will be more useful when the settlement process is also in the family.

\section{Reference List}

Hermawanti M \& Rinandari (2005)

Pemberdayaan Masyarakat Adat, IRE

Lexy J. Moleong 1989 "Metodologi Penelitian Kualitatif" Remaja Karya, Jakarta

Ligori, Tamar, 2014, Analisis Kebudayaan Suku Manggarai, http:// tamarligori.blogspot.co.id/2014/05/budayamanggarai.html, Diakses 27 Agustus 2017

Oktavianus, Agung Gampung, 2015, Konflik Tanah di Kabupaten Manggarai, Jounal Unair http://journal.unair.ac.id/ download-fullpapers-jpm3562dda0ecfull.pdf diakses Diakses 27 Agustus 2017

Minnery, John. R, 1985. Conflict Management In Urban Planning.Brookfield: Gower Publishing Company

Nasution 2003 "Metode Penelitian" Pustaka Ilmu, Jakarta

Novri, Susan, 2009, Pengantar Sosiologi Konflik, Jakarta, Kencana Prenadamedia Group

K. Yin Robert, 2002, Studi Kasus, Desain dan Metode, Rajawali Press, Jakarta

Kurniasari N \& Reswati E (2011) Kearifan lokal masyarakat Lamalera: sebuah 
ekspresi hubungan manusia dengan laut. Buletin Riset Sosek Kelautan dan Perikanan $6(2): 17-26$

Ndiung, Sabina. 2017. Ritus Tiba Meka Orang Manggarai Dalam Kajian Etnopedagogi, Prosiding, Universitas Muhammadiyah Surakarta, hal 811-829

Sartini (2004) Menggali kearifan lokal nusantara: sebuah kajian filsafati. Jurnal Filsafat, Fakultas Filsafat Universitas Gajah Mada 37 (2):21-34.

Soedjono. 2002. Misteri di Balik Kontrak Bermasalah, Bandung: Mandar Maju.
Sri Wahyuni, 2016 : http:// suryamalang.tribunnews.com/2016/03/20/ inilah-kronologi-tawuran-mahasiswa-yangrenggut-satu-nyawa, diakses 26 Agustus 2017

Suryanto \& Aniputra MGB (2012) Model penyelesaian konflik nelayan di Selat Madura berasis pada kearifan lokal sebagai modal sosial. Laporan Penelitian, Surabaya: LPPM Unair 